Later Mott turned to semi-conductors and insulators, throwing light on the physical processes involved in the formation of oxide films, and in the electrical conductivity which can be induced by various means in polar crystals. His theory (with Gurney) of the formation of the latent image in a photographic emulsion has found general acceptance, and has stimulated fresh experimental work in research departments of the industry.
This striking record of published work was achieved between 1928 and 1939 .

When war broke out Mott found that his activities as a quantum physicist had no direct application to the War. It is a tribute to his versatility and flexibility of mind that he could turn so quickly to a new field in classical physics, and make important contributions to the practical problem in connexion with which he now holds an important post.

\title{
ABORIGINAL AUSTRALIAN STRING FIGURES
}

\begin{abstract}
A $\mathrm{S}$ time goes on, more and more attention is given to primitive man in his physical, mental and cultural aspects, and among the last-named may be classed that singularly fascinating and complicated pursuit known to us as string figures. It is now nearly forty years since the first collection of string figures was made and described from Torres Straits by Rivers and Haddon, and since then there has been a steady interest in the subject and a mounting number of collections made in different parts of the world. The latest is embodied in an article by D. S. Davidson (Proc. Amer. Phil. Soc., 84, No. 6; Aug. 1941) in which he sums up our present knowledge of the subject and adds a most interesting collection made by him from the Australian aborigines.

That a goodly store was to be collected there was evident from Roth's illustrations of numerous Queens. land figures, unfortunately without directions for their making, published in 1902 ; from some collected by myself from a few restricted areas in 1914, and from Stanley's collections, again from north Queensland, in 1926. Mr. Davidson's studies form a muchneeded addition to our knowledge of the subject and are the more valuable in that he traces the possible connexions of these Australian figures with those occurring in other parts of Oceania. According to his conclusions, string figures are of comparatively recent introduction into Australia from Melanesia, as they are found in greatest numbers in north-west Queensland, whereas in Western Australia they are
\end{abstract}

almost lacking and what exist are of recent introduction.

Mr. Davidson considers that Australia, Melanesia, Micronesia and Polynesia comprise a major stringfigure area, and from the evidence of the string figures themselves suggests the possibility that they were brought into the Pacific by the Polynesians or Micronesians, and spread from the west into New Guinea and western Melanesia late in the prePolynesian period. He suggests also that the diffusion of string figures into the New World and Africa from some Asiatic point of origin might have taken several thousands of years, but he does not appear to consider their possible spontaneous generation in unrelated areas. This is known to have occurred recently among the Brahmins in India and seems likely to be an explanation of their world-wide distribution, seeing that string-or its equivalent-is co-existent with man.

Mr. Davidson has described and illustrated some seventy string figures and in addition gives a comparative chart of their distribution; there is also a bibliography. If one might venture a criticism of one of his descriptions, taking a loop off a digit would seem to indicate removing it, whereas in "Movement Z" it means making the loop common to right and left thumbs. But this is a detail and in no way impairs the interest and value of the contribution.

\section{K. RISHBETH.}

\section{THE MOA IN NEW ZEALAND}

\begin{abstract}
A RECENT valuable contribution to the natural history of New Zealand by Dr. G. Archey dealing with the moa* fully maintains the high reputation of the ornithologists of that country, and both the author and the Council of the Auckland Institute, who sponsored the work, merit our congratulations.

Almost from its inception the study of the moas has been accompanied by considerable confusion and uncertainty owing to the insufficient definition of types, and to the frequently erroneous association of different parts of the skeleton, an unsatisfactory state of affairs which Dr. Archey determined to remedy. After much patient work involving the examination of types and other specimens both in New Zealand

* The Moa : a Study of the Dinornithiformes. By Gilbert Archey. Bulletin of the Auckland Institute and Museum, No. 1. Pp. 119+15 plates +9 tables of Measurements. (Auckland: Auckland Institute and Museum, 1941.)
\end{abstract}

and in England he has produced this excellent monograph of the moas.

Perhaps the most urgent need was for a knowledge of the associated skeleton in the various forms, and in accumulating material for this the author tells how greatly he was helped by many enthusiastic field workers who, since 1930, have discovered and collected in different parts of the North and South Islands no less than fifty fairly complete skeletons, and more than a hundred partial sets of bones of individual birds. Among the facts revealed by this mass of authentic associated material is the hitherto unsuspected occurrence of parallelism in one division of the moas. The author writes ". . that two subfamilies with widely differing skulls, sterna and phalanges have independently embarked upon identical courses of development of shorter and heavier 
leg-bones" (p. 8). Good evidence is supplied in support of the claim that from the characters of both skull and skeleton the moas can be separated into two natural divisions: "the tall Dinornithidæ, with flattened broad skulls and the normal number of phalanges, are regarded as standing apart from the others." The second division absorbs the remainder, which thus includes a considerable number of genera and species. These two sections are the equivalent of Dr. Oliver's Dinornithidæ and Anomalopterygidæ. Careful diagnoses and descriptions are given of the genera and species, and these greatly help to bring order into this rather unwieldy group. In habits these birds appear to have been tolerant of different climatic conditions, vegetarian in their diet, and dwellers in open scrub and grassland. Dr. Archey refuses to credit the great Dinornis with a maximum height of twelve feet, and thinks that it cannot have exceeded a normal walking height of ten feet. The phylogeny of the moas is of paramount interest, being related to the problem of the origin of all the large flightless birds, but the author does little more than review this subject, although he seems inclined to cling to the belief in a loss of flight through degeneracy. Dr. Percy Lowe's brilliant anatomical researches, coupled with the discovery of an ever-increasing number of large fossil flightless birds in nearly every region of the globe, forces this old belief to appear in a somewhat fantastic light.

The last section of the book, entitled "Development and Extinction", includes much diverse information. The author concludes that the evidence all points to the "final extermination of the Moa by the earliest Polynesian immigrants a considerable time ago, first in the North Island and later in the South, and probably before the arrival of the immediate ancestors of the present Maori tribes in the Fleet migration of 600 years ago" (p. 97). There are also new and interesting details about the occurrence of the remains, notes on recent geological happenings affecting the moas, and so forth. The volume is completed with a comprehensive bibliography, a series of tables of measurements of limb bones, and fifteen plates. This brief notice should serve to show that this is a volume which will be indispensable to every serious ornithologist.

D. M. A. BATE.

\section{FORTHCOMING EVENTS}

[Meeting marked with an asterisk is open to the public.]

\section{SATURDAY, DECEMBER 6}

Institute of Physics (London and Home Counties' Branch) (at the South-West Essex Technical College, Forest Road, Walthamstow, London, E.17), at 2.30 p.m.-Dr. W. G. Wearmouth: "Physical Problems in the Plastics Industry".

MONDAY, DECEMBER 8

ROYAL GEOGRAPHical SocIETY (at Kensington Gore, London, S.W.7) at 3 . - Pieut I G. Trorey : Photographic Survey by High Obliques; the Canadian Plotter and Crone's Graphical Solution". TUESDAY, DECEMBER 9

Chadwick PUblic Lecture (at the Royal Society of Tropical Medicine and Hygiene, 26 Portland Place, London, W.1), at 2.30 p.m.Mrs. Blaise Gillie: "Post-War Housing in the Light of War-Time Experience".**

Illtminating Engineering Society (at the E.L.M.A. Lighting Service Bureau, 2 Savoy Hill, Iondon, W.C.2), at 2.30 p.m.-Mr. R. Maxted: "Infra-Red Radiation and Equipment, their Application to Industrial Processes".

Institution of Mechanical Engineers (Joint Meeting with the Institutions of Civil and Electrical Engineers) (at Central Hall, Westminster, London, S.W.1), at 10.45 a.m.- Conference on "Air Raid Precautions and the Engineering Industry".

ROYAL INSTITUTION OF GREAT BRITAIN (at 21 Albemarle Street London, W.1), at 2.30 p.m.-Prof. J. C. Drummond: "Recent Advances in the Science of Nutrition and their Significance in War-Time"'.
WEDNESDAY, DECEMBER 10

ROYAI SOcIETY of ARTS (at John Adam Street, Adelphi, London, W.C.2), at 1.45 p.m. - Miss Elizabeth Denby: "The Post-War Home-Its Interior and Equipment". 2: "Using Space to Advantage",

Physical Society (Colocr Group) (at the Electric Lamp Manufacturers' Association, 2 Savoy Hill, London, W.C.2), at 2.35 p.m.Dr. F. H. G. Pitt: "Colour Blindness and its Importance in Industry".

THURSDAY, DECEMBER 11

PHARMACECTICAI SOCIETY (at 17 Bloomsbury Square, London, W.C.1), Chemistry on Pharmacy" (Harrison Memorial Lecture).

FRIDAY, DECEMBER 12

NORTH-EAST COAST INSTITUTION OF ENGINEERS AND SHIPBUILDERS (a the Mining Institute, Newcastle-upon-Tyne), at 6 p.m.-Dr. A. Caress: "Plastics and Engineering".

\section{APPOINTMENTS VACANT}

APPLICATIONs are invited for the following appointments on or before the dates mentioned:

Proffssor of AGricutiture-The Principal, University College of Wales, Aberystwyth (January 15).

Junior Assistant Drainage and Irrigation Engineer by the Government of Sierra Leone--The Ministry of Labour and National Service, Central Register Branch, Queen Anne's Chambers, Tothil Street, London, S.W.1 (quoting E.339).

First Assistant Port Enginker for the Basrah Port Directorate, Government of Iraq-The Ministry of I Labour and National Service, Central Register- Branch Queen Anne's Chambers, Tothill Street, London, S.W.1 (quoting E.340).

Second Assistant PoRT Engineer for the Basrah Port Directorate, Government of Iraq-The Ministry of Labour and National Service, Central Register Branch, Queen Anne's Chambers, Tothill Street, London, S.W.1 (quoting E.341).

Senior assistant Drainage and IRrigation Engineer by the Government of Sierra Leone-The Ministry of Labour and National Service, Central Register Branch, Queen Anne's Chambers, Tothill Street, London, S.W.1 (quoting E.345).

Assistant ENGINEkR (CIVIL) for the Gold Coast Government Railway-The Ministry of Labour and National Service, Central Register Branch Queen Anne's Chambers, Tothill Street, London, S.W.1 (quoting E.346)

\section{REPORTS AND OTHER PUBLICATIONS}

(not included in the monthly Books Supplemenl)

\section{Great Britain and Ireland}

Interim Scheme for the Training and Resettlement of Disabled Pp. 8. (London: Ministry of Labour and National Service.

University of London: University College, Calendar, Session University of London : University College. Calendar, Session 1941-1942.
Francis, Ltd.)

\section{Other Countries}

Brooklyn Botanic Garden Record. Vol.'30, No. 4: Prospectus of Courses, Lectures and other Edueational Advantages offered to Members and to the General Public, 1941-1942. Pp. vi+225-251. Members and to the General Public, 1941-1942. Pp. vits.)
(Brooklyn, N.Y.: Brooklyn Institute of Arts and Sciences.) Trinidad and Tobago: Forest Department. Administration Report of the Conservator of Forests for the Year 1940. Pp. 6. (Trinidad Government Printer.) $6 d$.

[311

Government of Travancore. Administration Report of the Government Museum, 1115 M.E. Pp. ii +8 . (Trivandrum: Government Press.)

[311

Smithsonian Miscellaneous Collections. Vol. 101, No. 4: Diseases and Artifacts on Skulls and Bones from Kodiak Island. By Ale Hrdlicka. (Publication 3640.) Pp. ii $+14+11$ plates. (Washington,

Gold Coast Colony. Report on the Forest Department for the Year 1940-41. Pp. 6. (Accra: Government Printing Department London: Crown Agents for the Colonies.) 18 .
Editorial and Publishing Offices MACMILLAN \& CO., LTD. ST. MARTIN'S STREET, LONDON, W.C.2

Telephone: Whitehall 8831 Telegrams : Phusis Lesquare London Advertisements should be addressed to

T. G. Scots \& Son, Ltd., Three Gables, London Road, Merstham, Surrey Telephone: Merstham 316

The annual subscription rate is $£ 4100$, payable in advance, Inland or Abroad All rights reserved. Registered as a Newspaper at the General Post Office 